\title{
PENJATUHAN PIDANA OLEH HAKIM TERHADAP ANAK YANG BERHADAPAN DENGAN HUKUM
}

\author{
(Criminal Decision by The Judge of Children in Conflict with Laws)
}

\author{
Prihatin Effendi**, Dwi Wachidiyah Ningsih**, Hesti*
}

*Mahasiswa Fakultas Hukum Universitas Gresik, email: Hestiaprilia207@gmail.com

**Dosen Fakultas Hukum Universitas Gresik, email: dwiwachidiyah@gmail.com

\begin{abstract}
ABSTRAK
Penelitian ini bertujuan untuk mengetahui penerapan ketentuan hukum pidana materil terhadap tindak pidana pengedar narkotika golongan I jenis ganja dalam Putusan Pengadilan Negeri Gresik Nomor : 5/Pid.Sus-Anak/2018/PN.Gsk dan untuk mengetahui pertimbangan hukum hakim dalam menjatuhkan sanksi pidana pada pelaku tindak pidana pengedar narkotika golongan I jenis ganja dalam putusan PengadilanNegeri Gresik Nomor: 5/Pid.Sus-Anak/2018/PN.Gsk. Hasil penelitian menunjukkan bahwa (1) Penerapan ketentuan hukum pidana materil terhadap perkara putusan Nomor : 5/Pid.Sus-Anak/2018/PN.Gsk mestinya sesuai dengan tuntutan dari Jaksa Penuntut Umum. Karena dalam keterangan terdakwa yang dikemukakan dalam persidangan mengatakan adanya transaksi jual beli yang dilakukan oleh terdakwa dengan seseorang yang tidak dikenalnya. (2) Pertimbangan Hukum Hakim dalam menjatuhkan sanksi pidana perkara putusan Nomor : 5 / Pid.Sus-Anak / 2018 / PN.Gsk berdasarkan pertimbangan Penuntut Umum dan Hakim maka sanksi yang dijatuhkan mestinya tidak hanya 4 (empat) tahun dan denda sebesar Rp.800.000.000,-(delapan ratus juta rupiah) subsidair 4 (empat) bulan penjara, jika menerapkan pasal yang menjadi dasar hukum dalam tuntutan Jaksa Penuntut Umum yaitu Pasal 114 ayat (1) Undang-Undang No. 35 tahun 2009 tentang Narkotika Jo. Pasal 55 ayat (1) ke-1 KUH Pidana.
\end{abstract}

\section{Kata kunci :Anak bermasalah hukum; Narkotika.}

\section{ABSTRACT}

This study aims to find out the application of the provisions of the material criminal law against the criminal act of trafficking in class I narcotics in the Decision of the Gresik istrict Court Number: 5 / Pid.Sus-Anak / 2018 / PN. perpetrators of criminal acts of trafficking in class I narcotics in the decision of the Gresik istrict Court Number: 5 / Pid.Sus-Anak / 2018 / PN.Gsk.The results of the study indicate that (1) The application of the provisions of the material criminal law to the case of decision Number: 5 / Pid.Sus-Anak / 2018 / PN.Gsk should be in accordance with the demands of the Public Prosecutor. Because in the statement the defendant stated in the trial said that there was a sale and purchase transaction carried out by the defendant with someone he did not know. (2) Judges' Legal Considerations in imposing criminal sanctions for verdicts Number: 5 / Pid.Sus-Anak / 2018 / PN.Gsk based on the consideration of the Public Prosecutor and Judges, the sanctions imposed should not only be 4 (four) years and a fine of Rp.800,000. 000, - (eight hundred million rupiah) subsidies 4 (four) months in prison, if applying the article that becomes the legal basis in the demands of the Public Prosecutor, namely Article 114 paragraph (1) Law No. 35 of 2009 concerning Narcotics Jo. 1st Article 55 paragraph (1) of the Criminal Code.

Keywords: Legal troubled children, Narcotics. 


\section{A. Pendahuluan}

Anak adalah bagian yang tidak terpisahkan dari keberlangsungan hidup bangsa dan negara. Berkaitan dengan kedudukan anak yang memiliki kedudukan dan peran yang strategis, maka negara pun menjamin di dalam konstitusi tentang hak setiap anak atas kelangsungan hidup, tumbuh, berkembang serta perlindungan dari kekerasan dan diskriminasi Pasal 28 B Ayat(2)Undang-Undang Dasar 1945 Hasil amandemen. Oleh karena itu diperlukan upaya bersama dalam memperhatikan kepentingan anak, sehingga tidak terjerumus untuk melakukan perbuatan jahat yang merugikan pihak lain.

Menurut pasal 1 UU No.23 Tahun 2002 tentang perlindungan anak: "anak adalah seseorang yang belum berusia 18 (delapan belas) tahun. Termasuk anak yang masih dalam kandungan" anak memiliki peran strategis dan mempunyai ciri dan sifat khusus, sehingga memerlukan pembinaan dan perlindungan dalam rangka menjamin pertumbuhan dan perkembangan fisik , mental,sosial secara seimbang.

Undang Undang nomor 11 tahun 2012 tentang sistem peradilan pidana anak juga menegaskan bahwa anak yang berkonflik dengan hukum yang selanjutnya disebut dengan anak adalah anak yang berumur 12 (dua belas) tahun. Tetapi belum berumur 18 (delapan belas) tahun yang diduga melakukan tindak pidana. Pembedaan perlakuan tersebut didasarkan atas pertumbuhan dan perkembangan fisik, mental, dan sosial anak (Penjelasan UU No. 3 Tahun 1997 Tentang Pengadilan Anak). Anak yang berhadapan dengan hukum bisa dijatuhkan hukuman atau sanski yang berupa tindakan atau pidana apabila terbukti melanggar perundangan undangan hukum pidana.
Tindak pidana yang terjadi saat ini dimasyarakat bukan saja pelakunya orang dewasa, bahkan terjadi kecenderungan pelakunya adalah masih tergolong usia anak-anak (remaja). Oleh karena itu, berbagai upaya pencegahan dan penanggulangan kenakalan anak yang perlu segera dilakukan Prinsip perlindungan hukum terhadap anak di Indonesia diupayakan sesuai dengan konvensi hak-hak anak (convention on the Right of the Child) sebagaimana telah diratifikasi oleh pemerintah Indonesia dengan keputusan presiden (Keppres) Nomor 35 tahun 1990 tentang pengesahan Convention on The Right of the child ( tentang hak hak anak ).

Prinsip perlindungan anak diatur dalam undang undang nomor 23 tahun 2002 sebagaimana telah diubah dengan undang undang 35 tahun 2014 tentang perlindungan anak (selanjutnya disebut "UU No.35/2014") sebagaimana telah diubah dengan UU No. 35/2014 pada hakikatnya adalah pengintergrasian norma norma hukum internasional tentang hak-hak anak ke dalam tata hukum nasional lebih lanjut. Anak yang berkonflik dengan hukum Secara nasional definisi anak menurut perundang undangan diantaranya menyatakan anak adalah seorang yang belum mencapai usia 21(dua puluh satu) tahun belum menikah. Ada juga yang mengatakan Anak adalah seseorang yang belum berusia 18 (delapan belas tahun).pasal angka 1 angka 1 UU No. 23 Tahun 2002 jo UU No.35 Tahun 2014 tentang perlindungan Anak menyatakan bahwa Anak adalah seseorang yang belum berusia 18 (delapan belas) Tahun, termasuk Anak yang masih berada dalam kandungan, Sedangkan Pasal 1 angka 3 UU No.11 Tahun 2012 tentang Sistem Peradilan Pidana Anak menyatakan bahwa anak adalah seseorang yang telah berumur 12( dua belas) tahun, tetapi belum berumur 18 
(delapan belas) tahun yang diduga melakukan tindak pidana.

Pasal 6 Undang-Undang No. 4 Tahun 1979 Tentang Kesejahteraan Anak menyatakan bahwa anak yang mengalami masalah kelakuan diberi pelayanan dan asuhan yang bertujuan menolongnya guna mengatasi hambatan yang terjadi dalam masa pertumbuhan dan perkembangannya. Pelayanan dan asuhan tersebut juga diberikan kepada anak yang telah dinyatakan bersalah melakukan pelanggaran hukum berdasarkan keputusan hakim. Dari pasal tersebut telah dinyatakan dengan jelas bahwa undang-undang dengan tegas menyatakan dan mendorong pentingnya perlindungan anak dalam rangka mengusahakan kesejahteraan anak dan perlakuan yang adil terhadap anak. Pada pembuatan putusan dalam perkara anak hakim memiliki pertimbangan yang berbeda dengan pertimbangan dalam putusan untuk perkara dewasa.

Anak Bermasalah Hukum $(\mathrm{ABH})$ atau yang disebut juga Anak Nakal. Dalam Undang-Undang Nomor 3 Tahun 1997 Tentang Pengadilan Anak pada pasal 1 dijelaskan bahwa anak adalah orang yang dalam perkara anak nakal telah mencapai umur 8 (delapan) tahun tetapi belum mencapai umur 18 (delapan belas) tahun dan belum pernah kawin. Kemudian yang dimaksud Anak Nakal adalah anak yang melakukan tindak pidana atau anak yang melakukan perbuatan yang dinyatakan terlarang bagi anak, baik menurut peraturan perundang-undangan maupun menurut peraturan hukum lain yang berlaku dalam masyarakat yang bersangkutan.

\section{B. Metode Penelitian}

Tipe penelitian yang digunakan dalam penelitian hukum ini adalah penelitian hukum normatif yaitu dalam suatu penelitian yang menjadi sasaran utama yang dituju peneliti dinamakan objek penelitian. Untuk penelitian ini yang menjadi objek penelitian adalah putusan

No.5/Pid.Sus.Anak/2018/Pn.Gsk dan peraturan perundang undangan yang berhubungan dengan pidana anak.Pendekatan Masalah dalam penelitian hukum adalah : 1). Pendekatan perundang undangan (Statute Approach)Penelitian ini dilakukan dengan menelah UndangUndang dan regulasi yang bersangkut paut dengan isu hukum yang sedang ditangani, pendekatan ini juga bertujuan untuk mengetahui sinkronisasi peraturan perundang undangan secara vertikal maupun horizontal, secara vertikal melihat bagaimana hierarktis perundang undangan tersebut sedangkan secara horizontal diteliti sejauh mana perundang undangan yang mengatur berbagai bidang itu mempunyai hubungan fungsional secara konsisten. Tujuannya adalah agar penelitian ini dapat mengetahui kelemahan pada Peraturan Perundang Undangan yang digunakan dalam mengatur bidang bidang tertentu. 2). Pendekatan

Historis ( Historcal Approach )Pendekatan ini dilakukan latar belakang mengenai apa yang dipelajari dan perkembangan peraturan mengenai isu yang sedang dihadapi pendekatan ini mengungkap filosofi dan pola pikir. 3). Pendekatan Komparatif (Comparative Approach)Pendekatan ini dilakukan dengan membandingkan Putusan No.5/Pid.Sus-Anak/2018/Pn.Gsk dengan Undang Undang Nomor 35 Tahun 2009 tentang Narkotika Dan Undang Undang perlindungan Anak Pendekatan ini bertujuan untuk mengetahui persamaan dan perbedaan diantara undang undang tersebut.

\section{Pembahasan}

\section{Pengertian Anak Bermasalah Hukum}

Anak sebagai pelaku tindak pidana istilah yang digunakan adalah anak berhadapan dengan hukum 
sebelumnya dikenal dengan anak nakal. "Undang - Undang Nomor 3 merancunkan istilah anak pelaku tindak pidana dan anak nakal, hal ini sangat berbahaya karena "JuvenileDelinquent adalah hal biasa dan tidak perlu diproses pidana".

Menurut pasal 1 Angka 2 UU No. 3 Tahun 1997 tentang pengadilan Anak, menerangkan anak nakal adalah :

a. Anak yang melakukan tindak pidana

b. Anak yang melakukan perbuatan yang dinyatakan terlarang bagi anak, baik menurut peraturan peundang-undangan maupun menurut peraturan hukum lain ang hidup dan berlaku dalam masyarakat yang bersangkutan.

Kenakalan anak disebut juga dengan Juvenile Deliquency. Juvenile atau yang (dalam bahasa inggris) dalam bahasa Indonesia berarti anakanak. Anak muda, sedangkan Deliquency artinya terabaikan/ mengabaikan yang kemudian diperluas menjadi jahat, kriminal, pelanggar peraturan dan lain-lain. Sedangkan dalam Kamus Besar Bahasa Indonesia, delikuensi diartikan sebagai tingkah laku yang menyalahi secara ringan norma dan hukum yang berlaku dalam suatu masyarakat (Kamus Besar Bahasa Indonesia, 1991 : 219).

Suatu perbuatan dikatakan delinkuen apabila perbuatanperbuatan tersebut bertentangan dengan norma yang ada dalam masyarakat dimana ia hidup atau perbuatan yang anti sosial yang didalamnya terkandung unsur-unsur anti normative. Anak nakal atau kenakalan anak ini diambil dari istilah asing yaitu Juvenile Delinquency bila diartikan maka Juvenile artinya Young, anak-anak, anak muda, memiliki karakteristik kha periode kanak-kanak, sedangkan Delinquency artinya doingwrong, terabaikan/mengabaikan yang kemudian diperluas artinya menjadi jahat, asosial, kriminal, pelanggar aturan, pembuat ricuh, pengacau, penteror, tidak dapat diperbaiki lagi,durjana, dursila, dan lain-lain (Soetodjo 2010:8-9).

Menurut Fuad Hasan (Soetodjo 2010:10), yang dikatakan JuvenileDelinquery adalah perbuatan anti sosial yang dilakukan oleh remaja, yangapabila dilakukan oleh orang dewasa maka diualifikasikan sebagai kejahatan. Sedangkan R. Kusumanto Setyonegoro (Soetodjo, 2010:10-11)

Menurut Romli Atmasasmita: ${ }^{1}$

"Delinquency adalah suatu tindakan atau perbuatan yang dilakukan oleh seorang anak yang dianggap bertentangan dengan ketentuan-ketentuan hukum yang berlaku disuatu Negara dan oleh masyarakat itu sendiri dirasakan serta ditafsirkan sebagai perbuatan yang tercela".

Dalam hal ini mengemukakan pendapatnya antara lain sebagai berikut : "Tingkah laku individu yang bertentangan dengan syarat-syarat dan pendapat umum yang dianggap sebagai akseptable dan baik, oleh suatu lingkungan masyarakat atau hukum yang berlaku disuatu masyarakat yang berkebudayaan tertentu. Apabila individu itu masih anak-anak, maka sering tingkah laku serupa itu disebut dengan istilah tingkah laku yang sukat atau nakal. Jika ia berusaha adolescent atau preadolescent, maka tingkah laku itu sering delinkuen, dan jika ia dewasa maka tingkah laku ia sering disebut

${ }^{1}$ Romli Atmasasmita dkk, Peradilan Anak Di Indonesia. Bandung, Mandar Maju, 1977, hlm 15 
psikopatik dan jika terang-terangan melawan hukum disebut kriminal".

Sebagaimana telah diketahui terdapat berbagai macam definisi yang dikemukakan oleh para ilmuan tentang Juvenile Delinquency, dapat disimpulkan yang dimaksud dengan Juvenile Delinquency adalah suatu tindakan atau perbuatan pelanggar norma yang terdapat di dalam masyarakat yang dilakukan oleh anak-anak yang melakukan pelanggaran norma disebut sebagai anak nakal atau juvenile Delinquency yang mengabaikan norma atau asosial bukan sebagai kejahatan anak, sebab terlalu ekstrim untuk anak yang melakukan tindak pidana bukan mutlak kesalahan atau kehendak dari anak sendiri namun terdapat beberapa faktor yang melatar belakangi perbuatan tersebut dan hal demikian adalah proses alami dari setiap manusia dimana manusia mengalami kegocangan semasa menjelang kedewasaan.

Menurut Wagiati Soetodjo dan Melani: $^{2}$

"Kenakalan anak ini diambil dari istilah juveniledelinquency tetapi kenakalan anak ini bukan kenakalan yangsebagaimana dimaksud dalam Pasal 489 KUHPidana Juvenile artinya Young, anak-anak, anak muda, cirikarakteristik pada masa muda sifat-sifat khas pada periode remaja sedangkan delinquency artinya doing wrong, terabaikan/mengabaikan, yang kemudian diperluas artinya menjadi jahat, a-sosial, criminal, pelanggar aturan, pembuat rebut, pengacau, penteror, tidak dapat diperbaiki lagi, durjana, dursila dan lain-lainnya.

Anak nakal yang didapat diproses secara hukum diistilahkan sebagai Anak Berhadapan dengan Hukum

\footnotetext{
${ }^{2}$ Wagiati Soetodjo dan Melani. Op cit., hlm 9 .
}

$(\mathrm{ABH})$. Istilah anak berhadapan dengan hukum $(\mathrm{ABH})$ muncul dari Surat Keputusan Bersama (SKB) ketua Mahkamah Agung, Jaksa Agung, Kepala Kepolisian, Menteri Hukum dan HAM, Menteri Sosial, Menteri Pemberdayaan Perempuan dan Perlindungan Anak tentang penanganan Anak Berhadapan dengan Hukum (ABH) yang ditandatangani pada 22 Desember 2009 (DS. Dewi dan Fatahillah, 2011 : 9). SKB ini dibuat dengan tujuan untuk memberikan perlindungan dan rehabilitas sosial bagi $\mathrm{ABH}$ dengan mengutamakan keadilan restorative serta agar penanganannya telah terintegrasi dan terkoordinasi.

Ruang lingkup SKB mengatur tentang penanganan anak berhadapan dengan hukum, meliputi penanganan di tingkat penyidikan, penuntutan, pemeriksaan, pengadilan, pembimbingan, pendampingan, pelayanan, dan pembinaan pemasyarakatan, serta penanganan setelah ada keputusan pengadilan.

\section{Sanksi Pidana Terhadap Anak Bermasalah Hukum}

Menurut Pasal 22 Undang-Undang Normor 3 Tahun 1997 tentang pengadilan Anak, menyatakan bahwa : "Terhadap anak nakal hanya dapat dijatuhkan pidana atau tindakan yang ditentukan dalam Undang-Undang ini”. Adapun pidana yang dijatuhkan kepada Anak Nakal, berdasarkan Pasal 23 Undang-Undang Nomor 3 Tahun 1997 adalah : a. Pidana pokok dan pidana tambahan
a. Pidana pokok yang didapatkan dijatuhkan kepada Anak Nakal adalah:
1. Pidana penjara
2. Pidana kurungan
3. Pidana denda
4. Pidana pengawasan 
Selain Pidana pokok sebagaimana dimaksud dalam ayat (2) terhadap nak nakal dapat juga dijatuhkan pidana tambahan berupa perampasan barang-barang tertentu dan atau pembayaran ganti rugi. Ketentuan mengenai bentuk dan tata cara pembayaran ganti rugi diatur lebih lanjut dengan peraturan pemerintah. Berdasarkan pasal 24 ayat (1) Undang-Undang Nomor 3 Tahun 1997 tindakan yang dikenakan terhadap anak nakal meliputi:

1. Mengembalikan kepda orang tua, wali atau orang tua asuh

2. Menyerahkan kepada Negara untuk mengikuti pendidikan, pembinaan, dan latihan kerja.

3. Menyerahkan kepada

Departemen Sosial, atau

Organisasi Sosial

Kemasyarakatan yang

bergerak di bidang

pendidikan, pembinaan dan

latihan kerja.

Berdasarkan Pasal 26 UndangUndang Nomor 3 Tahun 1997 tentang Pengadilan Anak, Hakim dalam memutuskan penjatuhan pidana kepada anak nakal adalah sebagai berikut :

1) Pidana penjara yang didapat dijatahkan kepada anak nakal, paling lama setengah dari maksimum pidana penjara bagi orang dewasa.

2) Apabila anak nakal melakukan tindak pidana yang diancam dengan pidana mati ata pidana penjara seumr hdup maka pidana penjara yang dapat dijatuhkan kepada anak tersebut paling lama 10 tahun.

3) Apabila anak nakal belum mencapai umur 12 tahun melakukan tindakan pidana diancam pidana mati atau pidana seumur hidup, maka terhadap anak nakal tersebut hanya dapat dijatuhkan tindakan menyerahkan kepada Negara untk mengikuti pendidikan, pembinaan dan latihan kerja.

4)Apabila anak nakal belum mencapai umur 12 tahun melakukan tindak pidana yang tidak diancam pidana mati atau tidak diancam pidana penjara seumur hidup, maka terhadap anak nakal tersebut dijatuhkan salah satu tindakan sebagaimana dimaksud dalam Pasal 243.

\section{Konsep Perlindungan Anak Yang Berkonflik Dengan Hukum.}

Seorang anakyang melakukan tindak pidana sangat membutuhkan perlindungan hukum bagi dirinya. Adapun prinsip-prinsip perlindungan menurut Irwanto:

1. Anak Tidak Dapat Berjuang SendiriAnak adalah modal utama kelangsungan hidup manusia, bangsa, dan keluarga, untuk itu hak-haknya harus dilindungi.

2. Kepentingan Terbaik Bagi Anak (the best interst of thechild)Perinsip ini menyatakan bahwa kepentingan terbaik bagi anak harus dipandang of paramount importence (memperoleh prioritas tinggi) dalam setiap keputusan yang menyangkut anak.

3. Ancangan Daur Kehidupan (LifeCircle Approach)Perlindungan anak mengacu pada pemahahaman bahwa perlindungan harus dimulai sejak dini dan terus menerus.

4. Lintas Sektoral

Nasib anak tergantung dari berbagai faktor yang makro maupun mikro yang langsung maupun tidak langsung.

Pada Pasal 37 Konvensi Hak-hak Anak ditegaskan pula bahwa Negaranegara peserta harus menjamin perlindungan terhadap anak dan inti dari Pasal 37 adalah tentang larangan terhadap penyiksaan, perlakuan atau hukuman yang kejam, hukuman 
mati, penjara seumur hidup, dan penahanan semena-mena atau perampasan kebebasan terhadap anak/

Dalam upaya memberikan perlindungan terhadap kepentingan dan hak-hak anak yang berhadapan dengan hukum. Pemerintah Indonesia telah mengeluarkan peraturan perundang-undangan terkait, antara lain UU No. 39 Tahun 1999 tentang Hak Asasi Manusia 11 Tahun 2012 tentang Sistem Peradilan Pidana Anak dan UU No. 23 Tahun 2003 tentang Perlindungan Anak.

Masalah perlindungan hak-hak anak yang berkonflik dengan hukum yang terdapat pada Pasal 66 UU No. 39 tahun 1999 tentang Hak Asasi Manusia menjelaskan bahwa:

a. Setiap anak berhak untuk tidak dijadikan sasaran penganiayaan, penyiksaan, atau penjatuhan hukuman yang tidak manusiawi.

b. Hukuman mati atau hukuman seumur hidup tidak dapat dijatuhkan untuk pelaku tindak pidana yang masih anak.

c. Setiap anak berhak untuk tidak dirampas kebebasannya secara melawan hukum.

d. Penangkapan, penahanan, atau pidana penjara anak hanya boleh dilakukan sesuai dengan hukum yang belaku dan hanya dapat dilaksanakan sebagai upaya terakhir.

e. Setiap anak yang dirampas kebebasannya berhak mendapatkan perlakuan secara manusiawi dan dengan memperhatikan kebutuhan pengembangan pribadi sesuai dengan usianya dan harus dipisahkan dari orang dewasa, kecuali demi kepentingannya.

f. Setiap anak yang dirampas kebebasannya berhak memperoleh bantuan hukum atau bantuan lainnya secara efektif dalam setiap tahapan upaya hukum yang berlaku.

g. Setiap anak yang dirampas kebebasannya berhak untuk membela diri dan memperoleh keadilan di depan Pengadilan Anak yang objektif dan tidak memihak dalam sidang yang tertutup untuk umum.

Sehubungan dengan terhadap perlindungan terhadap anak maka menurut UU No. 11 tahun 2012 tentang Sistem Peradilan Pidana Anak ini tidak selalu anak pelaku tindak pidana harus mendapatkan hukuman penjara. Sebagaimana ditegaskan pada Pasal 71 UU No. 11 Tahun 2002 tentang Sistem Peradilan Pidana Anak, bahwa tindakan yang dapat dijatuhkan kepada anak yang berkonflik dengan hukum, berupa pengembalian kepada orang tua, wali/orang tua asuh atau menyerahkan kepada Negara untuk mengikuti pendidikan pembinaan dan latihan kerja atau menyerahkan kepada departemen sosial atau organisasi sosial kemasyarakatan yang bergerak dibidang pendidikan, pembinaan dan latihan kerja.

Selanjutnya ketentuan yang terdapat dalam UU No. 23 Tahun 2002 jo UU No. 35 Tahun 2014 tentang Perlindungan Anak ada beberapa pasal yang berhubungan dengan masalah perlindungan anak yang berhadapan dengan hukum.

a. Pasal 1 angka 2 menyebutkan Perlindungan Anak adalah segala kegiatan untuk menjamin dan melindungi Anak dan hakhaknya agar dapat hidup, tumbuh, berkembang, dan berpartisipasi secara optimal sesuai dengan harkat dan martabat kemanusiaan, serta mendapat perlindungan dari kekerasan dan diskriminasi.

b. Pasal 1 angka 15 Perlindungan Khusus adalah suatu bentuk perlindungan yang diterima oleh 
Anak dalam situasi dan kondisi tertentu untuk mendapatkan jaminan rasa aman terhadap ancaman yang membahayakan diri dan jiwa dalam tumbuh kembangnya.

c. Pasal 2 penyelenggaraan perlindungan anak berdasarkan Pancasila dan berlandaskan UUD 1945 serta prinsip dasar Konvensi Hak-hak Anak meliputi:

1. Non diskriminasi

2. Kepentingan yang terbaik bagi anak

3. Hak untuk hidup, kelangsungan hidup dan perkembangan

4. Penghargaan terhadap pendapat anak.

d. Pasal 3, menentukan bahwa perlindungan anak bertujuan untuk menjamin terpenuhinya hak-hak anak agar dapat hidup, tumbuh, berkembang, dan berpartisipasi secara optimal sesuai dengan harkat martabat kemanusiaan, serta mendapat perlindungan dari kekerasan dan diskriminasi, demi terwujudnya anak Indonesia berkualitas, berakhlak mulia dan sejahtera.

e. Pasal 59 ayat (1) dan ayat (2) disebutkan

Ayat (1) Pemerintah,

Pemerintah Daerah, dan lembaga negara lainnya berkewajiban dan bertanggung jawab untuk memberikan Perlindungan Khusus kepada Anak.

Ayat (2) Perlindungan Khusus kepada Anak sebagaimana dimaksud pada ayat diberikan kepada:

1. Anak dalam situasi darurat;

2. Anak yang berhadapan dengan hukum;

3. Anak dari kelompok minoritas dan terisolasi;

4. Anak yang dieksploitasi secara ekonomi dan/atau seksual;
5. Anak yang menjadi korban penyalahgunaan narkotika, alkohol, psikotropika, dan zat adiktif lainnya;

6. Anak yang menjadi korban pornografi;

7. Anak dengan HIV/AIDS;

8. Anak korban penculikan, penjualan, dan/atau perdagangan;

9. Anak korban Kekerasan fisik dan/atau psikis;

10. Anak korban kejahatan seksual;

11. Anak korban jaringan terorisme;

12. Anak Penyandang Disabilitas;

13. Anak korban perlakuan salah dan penelantaran;

14. Anak dengan perilaku sosial menyimpang; dan

15. Anak yang menjadi korban stigmatisasi dari pelabelan terkait dengan kondisi Orang Tuanya.

f. Pasal 64 Perlindungan Khusus bagi Anak yang berhadapan dengan hukum sebagaimana dimaksud dalam Pasal 59 ayat (2) huruf $\mathrm{b}$ dilakukan melalui:

1. perlakuan secara manusiawi dengan memperhatikan kebutuhan sesuai dengan umurnya;

2. pemisahan dari orang dewasa;

3. pemberian bantuan hukum dan bantuan lain secara efektif;

4. pemberlakuan kegiatan rekreasional;

5. pembebasan dari penyiksaan, penghukuman, atau perlakuan lain yang kejam, tidak manusiawi serta merendahkan martabat dan derajatnya;

6. penghindaran dari penjatuhan pidana mati dan/atau pidana seumur hidup;

7. penghindaran dari penangkapan, penahanan atau penjara, kecuali sebagai upaya terakhir dan dalam waktu yang paling singkat;

8. pemberian keadilan di muka pengadilan Anak yang 
objektif, tidak memihak, dan dalam siding yang tertutup untuk umum;

9. penghindaran dari publikasi atas identitasnya.

10. Pemberian pendampingan Orang Tua/Wali dan orang yang dipercaya oleh Anak;

11. pemberian advokasi sosial;

12. pemberian kehidupan pribadi;

13. pemberian aksesibilitas, terutama bagi Anak Penyandang Disabilitas;

14. pemberian pendidikan;

15. pemberian pelayanan kesehatan; dan

16. pemberian hak lain sesuai dengan ketentuan peraturan perundang-undangan.

Maka dari itu perlindungan terhadap anak diperlukan untuk menjaga kelangsungan hidup hidup anak yang berkonflik dengan hukum.

\section{Faktor-Faktor Yang Dapat Mempengaruhi Tindak Pidana Anak}

Menurut Sri Widoyanti: ${ }^{3}$

a. Keluarga yang Broken Home

1. Keadaan ekonomi

2. Sikap masyarakat terhadap anggota masyarakat

3. Kepadatan penduduk

4. Lingkungan pendidikan

5. Pengaruh Film, Televisi, dan hiburan lain

6. Perasaan disingkirkan oleh teman-teman

7. Sifat anak itu sendiri.

Seorang anak yang melakukan atau diduga melakukan tindak pidana sangat diperlukan adanya perlindungan hukum.

Pada masa anak-anak adalah masa yang sangat rawan melakukan tindakan, karena masa anak-anak suatu masa yang sangat rentan dengan berbagai keinginan dan harapan untuk mencapai sesuatu ataupun melakukan sesuatu. Seorang anak dalam melakukan sesuatu tidak/kurang menilai akibat akhir tindakan yang diambilnya. Dan oleh karena Faktor internal adalah faktor yang berasal dari dalam diri anak itu sendiri yang mempengaruhi tingkah lakunya, seperti cacat yang bersifat biologis dan psikis dan perkembangan kepribadian dan intelegensi yang terhambat sehingga tidak bisa menghayati norma-norma yang berlaku. Sedangkan faktor eksternal adalah faktor yang berasal dari luar diri anak yang mempengaruhi anak tingkah lakunya. $^{4}$

a) Faktor internal terdiri dari:

1) Faktor inteligensia;

2) Faktor kelamin;

3) Faktor usia.

b) Faktor Eksternal terdiri dari:

1) Faktor ekonomi;

2) Faktor pergaulan anak.

Dalam masalah perlindungan hukum bagi anak merupakan salah satu melindungi tunas bangsa di masa depan. Perlindungan hukum menyangkut semua aturan hukum yang berlaku. Perlindungan ini perlu karena anak merupakan bagian masyarakat yang mempunyai keterbatasan secara fisik dan metalnya. Oleh karena itu anak memerlukan perlindungan dan perwatan khusus.

Dalam UU No. 23 Tahun 2002 jo UU No. 35 Tahun 2014 tentang Perlindungan Anak, dinyatakan bahwa :

"Pemerintah dan lembaga Negara lainnya wajib memberikan perlindungan khusus kepada anak dalam situasi darurat, anak yang berhadapan dengan hukum, anak dari kelompok minoritas da

4 Angger Sigit Pramukti, Fuady Primaharsya, Sistem Peradilan Anak, Yogyakarta, Pustaka Yustisia, 2015, hal 18 
terisolasi, anak yang tereksploitasi secara ekonomi dan atau seksual, anak yang diperdagangkan, anak yang menjadi korban penyalahgunaan narkotika, alcohol, psikotropika, zat adiktif lainnya, anak korban penculikan, penjualan, dan perdagangan, anak korban kekerasan baik fisik maupun mental, anak yang menyadang cacat, dan anak korban perlakuan salah dan penelantaran".

\section{Dasar Pertimbangan Hakim dalam Menjatuhkan Putusan Pidana Terhadap Pelaku Tindak Pidana anak}

Sebelum memutuskan suatu perkara, hakim selalu memperhatikan hal-hal yang dapat menjadi suatu pertimbangan-pertimbangan baik secara yuridis maupun di luar ketentuan-ketentuan yuridis demi menemukan suatu kebenaran dan menciptakan keadilan. Sesuai dengan asas tindak pidana tanpa kesalahan (geen straaf zonder schuld) pidana hanya dapat dijatuhkan bila ada kesalahan terdakwa, yang dibuktikan di sidang pengadilan, yaitu kesalahan terdakwa sebagaimana dimaksud dalam dakwaan penuntut umum. Jadi pengadilan menjatuhkan pidana apabila terdakwa bersalah melakukan tindakan pidana yang didakwakan kepadanya (Pasal 193 KUHP). Bukan begitu saja dapat dijatuhi pidana tetapi, harus didukung dengan alat bukti yang sah sesuai dengan rumusan pasal 183 KUHP yang menegaskan bahwa:

"Hakim tidak pidana menjatuhkan pidana kepada seseorang kecuali apabila dengan sekurang-kurangnya dua alat bukti yang sah dan ia memperoleh keyakinan bahwa tindakan pidana benar-benar terjadi dan bahwa terdakwalah yang bersalah melakukannya."
Ada beberapa jenis bentuk putusan yang dapat dijatuhkan oleh pengadilan, yaitu :

a. Putusan bebas

Adalah putusan yang dijatuhkan apabila pengadilan berpendapat bahwa kesalahan terdakwa atas perbuatan yang didakwakan kepadanya "tidak terbukti" secara sah dan meyakinkan.

b. Putusan lepas dari segala tuntutan hukum

Adalah putusan yang dijatuhkan oleh pengadilan apabila pengadilan berpendapat bahwa perbuatan yang didakwakan kepada terdakwa terbukti, tetapi perbuatan itu tidak merupakan suatu tindak pidana.

c. Putusan pemidanaan

Adalah putusan yang dijatuhkan apabila pengadilan berpendapat dan menilai bahwa terdakwa terbukti bersalah melakukan perbuatan yang didakwakan kepadanya.

Disamping putusan-putusan tersebut di atas, masih ada putusanputusan yang lainnya, yaitu putusan yang menyatakan dakwaan tidak dapat diterima, putusan yang menyatakan dakwaan batal demi hukum, dan juga putusan yang bersifat penetapan, misalnya penetapan tidak berwenang mengadili dan penetapan untuk tidak menjatuhkan pidana akan tetapi berupa tindakan hakim, seperti memasukkan terdakwa ke rumah sakit jiwa. Seorang hakim harus memperhitungkan sifat dan tingkat keseriusan delik yang dilakukan, keadaan yang meliputi perbuatanperbuatan yang dihadapkan kepadanya serta melihat kepribadian dari pelaku perbuatan dengan umurnya, tingkat pendidikan, jenis kelamin, lingkungan, dan lain sebagainya.

Telah dikemukakan di muka bahwa seorang hakim menjatuhkan 
putusan atas perkara pidana anak berdasarkan Case Study yang telahterlebih dahulu dibuat oleh social worker. Dengan melihat Case Study tersebut, hakim dapat memilih satu dari dua kemungkinan hukuman yang dapat dijatuhkan yang ada pada Pasal 22 Undang-Undang No. 3 Tahun 1997 Tentang Pengadilan Anak, yaitu dijatuhi pidana (bagi anak yang telah berumur di atas 12 tahun sampai 18 tahun) atau tindakan (bagi anak yang masih berumur 8 tahun sampai 12 tahun) yang ditentukan dalam undang-undang tersebut.

Dalam pasal 23 Undang-Undang No. 3 Tahun 1997 Tentang Pengadilan Anak telah menentukan bentuk pidana yang dapat dijatuhkan kepada anak nakal yaitu pidana pokok dan pidana tambahan. Pasal 23 Ayat (2) undang-undang tersebut menyatakan pidana pokok yang dapat dijatuhkan kepada anak nakal ialah :

1. Pidana penjara;

2. Pidana kurungan;

3. Pidana denda; atau

4. Pidana pengawasan.

Berikut jenis-jenis alat bukti yang terdapat dalam pasal 184 KUHP, yaitu:

1. Keterangan saksi.

2. Keterangan ahli.

3. Surat.

4. Petunjuk.

5. Keterangan terdakwa.

Hal-hal tersebut harus diperhatikan untuk menjamin obyektifitas tegaknya kebenaran, keadilan dan kepastian hukum. Selain itu hakim menjaga tertib sidang, menguasai hukum materil, menjaga hak-hak terdakwa, mengusai hukum acara (hukum formil). Hakim sebagai penegak hukum dan keadilan wajib menggali, mengikuti, dan memahami nilainilai hukum yang hidup di dalam masyarakat. Masyarakat di Indonesia masih mengenal adanya hukum tidak tertulis. Hakim merupakan perumus dan penggali nilai-nilai hukum yang tumbuh dan berkembang di dalam masyarakat, sehingga hakim dapat memutuskan dengan rasa keadilan dan dapat dipertanggungjawabkan terhadap masyarakat.

\section{Faktor-faktor}

yang

Mempengaruhi Putusan Hakim

dalam Menjatuhkan Putusan

Pidana Terhadap Pelaku Tindak

Pidana Narkotika.

Putusan hakim dalam menjatuhkan pidana terhadap tindak pidana narkotika dipengaruhi oleh faktor eksternal dan internal yang dapat mempengaruhi perilaku hakim dalam menyelesaikan perkara. Faktor eksternal misalnya, tekanan pemerintah demi terciptanya kepentingan yang menyangkut wibawa pemerintah ataupun demi kepentingan lainnya. Kadang pemerintah turut campur dalam kasus-kasus tertentu dan juga adanya tekanan dari kelompok-kelompok tertentu untuk memaksakan kehendaknya atau turut campur dalam persidangan.

Apabila hakim tidak mempunyai kepribadian yang kuat dan tidak teguh pendirianya sebagai penegak hukum dan keadilan, maka tekanan dari luar ini dapat berpengaruh sekali dalam mengambil suatu keputusan. Tekanan keadaan juga mempengaruhi hakim secara internal, tekanan keadaan ini adalah suatu keadaan pada saat yang harus dihadapi oleh hakim di dalam menjalankan tugasnya. Tidak berbeda dengan anggota-anggota masyarakat yang lain, maka seorang hakim sebagai anggota masyarakat juga menepati kedudukan tertentu di dalamnya. Kedudukan tertentu ini tidak dapat ditetapkan atau dikehendaki secara otonomi oleh orang-orang yang bersangkutan. Apa yang ingin dilakukan atau dikehendaki oleh seorang hakim dapat ditentukan 
sendiri secara penuh, melainkan sangat tergantung pula akan nilainilai dan susunan masyarakat.

Faktor internal yang dapat mempengaruhi hakim dalam mengambil suatu keputusan adalah:

1. Subyektif

a. Sikap perilaku yang apriori, seringkali hakim dalam mengadili satu perkara sejak awal dihinggapi suatu prasangka atau dugaan bahwa tersangka atau terdakwa bersalah, sehingga harus dihukum atau dinyatakan sebagai pihak yang salah. Sikap ini jelas bertentangan dengan asas yang dijunjung tinggi dalam peradilan yaitu asas praduga tak bersalah.

b. Sikap perilaku emosional, perilaku hakim yang mudah tersinggung atau marah akan berbeda dengan perilaku hakim yang penuh pengertian, sabar dan teliti dalam menangani suatu perkara. Hal ini jelas akan berpengaruh pada hasil keputusannya.

c. Sikap perilaku arogan, hakim yang memiliki sikap arogan merasa dirinya berkuasa dan pandai melebihi orang lain sering kali mempengaruhi keputusannya.

d. Moral, faktor ini merupakan landasan yang sangat vital bagi penegak hukum dan keadilan terutama hakim.

2. Obyektif

a. Latar belakang Sosial, Budaya, dan Ekonomi Latar belakang sosial seorang hakim mempengaruhi sikap perilaku hakim. Dalam kajian sosiologis menunjukkan bahwa hakim yang berasal dari status sosial tinggi berbeda cara memandang suatu permasalahan yang ada dalam masyarakat, bila dibandingkan dengan hakim yang berasal dari lingkungan status sosial menengah ke bawah. Kebudayaan atau pendidikan seorang hakim juga ikut mempengaruhi suatu keputusan hakim.

Hakim yang berasal dari lingkungan budaya yang keras dan liberal tentu akan berbeda dalam menangani suatu perkara dibanding dengan hakim yang berasal dari lingkungan budaya yang halus, longgar, dan kekeluargaan. Pendidikan seorang hakim juga ikut mempengaruhi sikap perilakunya.

Hakim yang rajin mengikuti pendidikan tambahan, sepeti penataran, kursus-kursus atau bahkan melanjutkan pendidikan yang stratanya lebih tinggi tentu akan memiliki lebih banyak dasar pertimbangan dalam memutus sautu perkara, dibanding dengan seorang hakim yang hanya mengandalkan pendidikan sarjana hukumnya. Satu hal lagi yang banyak mempengaruhi perilaku hakim adalah latar belakang ekonomi.

Sebagai manusia biasa yang harus mencukupi kebutuhan hidupnya dan keluarganya, faktor ekonomi seringkali mempengaruhi pola pikirnya. Bisa saja karena desakan ekonomi, seorang hakim yang awalnya memiliki komitmen kuat, secara berangsur-angsur lemah pendiriannya dan menjadi pragmatis. Pada taraf yang paling parah, faktor ini bahkan bisa mendorong hakim berani melakukan tindakan yang salah hanya karena demi mendapatkan imbalan materi. Faktor ini tentunya tidak bersifat absolut, sebab hakim yang memegang teguh kode etik kehormatan hakim, tidak dapat dipengaruhi oleh faktor apapun termasuk desakan ekonomi.

b. Profesionalisme-Profesionalisme yang meliputi pengetahuan, wawasan, dan keahlian yang ditunjang dengan ketelitian merupakan faktor yang 
mempengaruhi cara hakim dalam mengambil keputusan. Masalah profesionalisme ini juga seringkali dikaitkan dengan kode etik di lingkungan peradilan, oleh karena itu hakim yang menangani suatu perkara dengan berpegang teguh pada etika profesi tentu akan menghasilkan putusan yang lebih dapat dipertanggungjawabkan, jika dibandingkan dengan hakim yang kurang mengindahkan etika profesi. Sekalipun keduanya memiliki tujuan yang sama yaitu menyelesaikan perkara, menegakkan hukum dan memberikan keadilan.

c. Faktor-faktor tersebut menurut penulis sangat relevan jika dikaitkan dengan penjatuhan pidana terhadap tindak pidana penyalahgunaan narkotika. Apabila seorang hakim mempunyai sikap yang apriori, emosional, atau arogansi, maka dapat saja penjatuhan pidananya diperberat. Namun apabila seoarang hakim mempunyai sikap yang arif dan bijaksana, maka hakim tersebut akan mempertimbangkan banyak faktor, terutama dari sisi nilai sosial dan nilai kemanusiaan, dapat menyebabkan hakim menjatuhkan pidana yang dapat meringankan terdakwa.

Sikap terdakwa yang sopan, masa depan terdakwa yang masih panjang, serta penyebab terdakwa melakukan tindak pidana atau penyalahgunaan narkotika tentu dijadikan sebagai dasar pertimbangan tersendiri oleh hakim. Seorang terdakwa yang baru pertama kali dihukum akibat salah pergaulan, tentu penjatuhan sanksinya akan berbeda dengan seorang terdakwa yang telah berulang kali dihukum. Seorang terdakwa yang baru pertama kali dihukum dan dijatuhi hukuman yang meringankan terdakwa oleh hakim, maka hakim mempunyai penilaian bahwa tingkah laku terdakwa masih dapat diperbaiki.

Sekalipun terikat pada suatu sistem yang ketat namun hakim dan peradilan tidak identik dengan mesin peradilan yang dapat bekerja secara sistematis atau mekanis dalam menyelesaikan perkara. Alasan sebenarnya sangat jelas dan sederhana, pertama karena hakim adalah manusia yang dapat bekerja dengan akal budinya, sehingga dalam menyelesaikan suatu perkara tidak cukup hanya mengandalkan daya pikir dan keterampilan dalam mengoperasionalisasikan hukum, namun juga berlandaskan moral yang muncul dari hati nuraninya. Kasus yang bervariasi dapat berpengaruh terhadap putusan hakim, namun hal ini tentu saja masih tergantung dari banyak faktor, seperti situasi, dan kondisi masyarakat, sistem pengawasan dan lain-lainnya. Faktor lain yang paling menentukan adalah sikap dari hakim itu sendiri dalam mengadapi kasus-kasus tersebut.

bahwa jenis-jenis kasus di pengadilan jika dikaitkan dengan kondisi hakim yang dapat berpengaruh terhadap hasil putusan antara lain dapat dijelaskan sebagai berikut :

1. Jika dikaitkan dengan profesionalisme hakim, maka ada perkara yang sederhana dan ada perkara sulit. Bagi hakim yang profesional (dalam arti keterampilan yang memadai dan berpengalaman), variasi perkara itu tidak menjadi masalah, namun bagi hakim yang masih kurang dalam pengalaman, maka akan berpengaruh sekali dalam menangani perkara sulit.

2. Jika dikaitkan dengan semangat hakim, maka ada perkara yang menarik dan membuka tantangan baru. Perkara-perkara semacam ini dapat memacu semangat hakim 
untuk belajar, berkembang, dan berusaha menyelesaikan sebaikbaiknya. Sebaliknya, apabila ada perkara yang ditangani bersifat monoton dan rutin maka dapat menimbulkan kejenuhan bagi hakim.

3. Jika dikaitkan dengan kepribadian hakim, maka ada perkara yang menyangkut obyek perkara kecil, beresiko tinggi, dan bersifat ketat. Namun ada juga perkara yang menyangkut obyek perkara yang besar yang tidak beresiko, dalam arti menyimpan kemungkinan untuk berkolusi. Bagi hakim yang memiliki kepribadian kuat dan teguh berpegang pada komitmen sebagai penegak hukum dan keadilan, maka jenis-jenis perkara seperti itu tidak ada pengaruhnya, karena yang menjadi tujuannya adalah bagaimana memutuskan perkara dengan sebaik-baiknya dan seadil adilnya. Dalam menjatuhkan pidana terhadap pelaku tindak pidana narkotika tidak hanya memperhatikan atau menilai terdakwa di luar pengadilan saja, dalam arti kelakuan terdakwa di masyarakat yang dijelaskan oleh keterangnan saksi, tetapi juga memperhatikan kelakuan terdakwa di persidangan.

\section{Penutup}

\section{Kesimpulan}

Dalam kasus mengedarkan narkotika golongan 1 atas nama Yustyawan maulana alias engkes bin jumadi yang mana berkedudukan sebagai terpidana" dalam putusan No.5/Pid.Sus-Anak/2018/PN.Gsk.

pengadilan negri gresik yang diangkat sebagai objek penelitian ini. Dalam salinan berkas putusan dinyatakan bahwa terdakwa $(\mathrm{ABH})$ Yustiawan maulana alias engkes bin jumadi terbukti bersalah secara sah meyakinkan bersalah melakukan tindakan"tanpa hak atau melawan hukum menjual, membeli narkotika golongan 1 bukan tanaman. Yaitu berupa barang bukti 1 (plastik) klip yang didalamnya berisi Kristal warna putih diduga narkotika jenis shabu dengan timbang 0,35 nol koma tiga puluh lima gram) dan dijatuhi pidana penjara selama 1(satu) tahun serta pelatihan kerja selama 3(tiga) bulan. Dan putusan dalam perkara anak hakim memiliki pertimbangan yang berbeda dengan pertimbangan dalam putusan untuk perkara dewasa. Namun tujuannya tetap sama, yaitu keadilan. Pertimbangan tersebut harus didasarkan pada kesejahteraan dan massa depan anak, jangan sampai anak tidak dapat melanjutkan hidupnya dengan layak sebagaimana mestinya, dalam mengambil keputusan, Hakim harus benar benar memperhatikan kedewasaan emosional, mental dan intelektual anak harus di hindarkan dari putusan hakim yang mengakibtkam penderitaan bathin seumur hidup atau dendam pada anak, dengan kesadaran bahwa putusan hakim bermotif perlindungan.

\section{Saran}

Sikap terdakwa yang sopan, masa depan terdakwa yang masih panjang, serta penyebab terdakwa melakukan tindak pidana atau penyalahgunaan narkotika tentu dijadikan sebagai dasar pertimbangan tersendiri oleh hakim. Seorang terdakwa yang baru pertama kali dihukum akibat salah pergaulan, tentu penjatuhan sanksinya akan berbeda dengan seorang terdakwa yang telah berulang kali dihukum. Seorang terdakwa yang baru pertama kali dihukum dan dijatuhi hukuman yang meringankan terdakwa oleh hakim, maka hakim mempunyai penilaian bahwa tingkah laku terdakwa masih dapat diperbaiki.

Sekalipun terikat pada suatu sistem yang ketat namun hakim dan peradilan tidak identik dengan mesin peradilan yang dapat bekerja secara sistematis atau mekanis dalam menyelesaikan perkara. 
Alasan sebenarnya sangat jelas dan sederhana, pertama karena hakim adalah manusia yang dapat bekerja dengan akal budinya, sehingga dalam menyelesaikan suatu perkara tidak cukup hanya mengandalkan daya pikir dan keterampilan dalam mengoperasionalisasikan hukum, namun juga berlandaskan moral yang muncul dari hati nuraninya.

\section{DAFTAR PUSTAKA}

Apong Herlina,dkk, perlindungan terhadap Anak Yang Berhadapan Dengan Hukum, Buku saku Untuk polisi, Unicef Jakarta,2014.

Angger Sigit Pramukti, Fuady Primaharsya, Sistem Peradilan Anak, Yogyakarta, Pustaka Yustisia

MaidinGultom, 2012, Perlindungan Hukum Terhadap Anak dan Perempuan, Bandung PT. Revika Aditama,

Maidan Gultom, Perlindungan Hukum Terhadap Anak, Bandung Aditama, 2008

Nandang Sambas, 2010, Pembaharuan Sistem Pemidanaan Anak di Indonesia, Graha Ilmu, Yogyakarta.

Romli Atmasasmita dkk, Peradilan Anak Di Indonesia. Bandung, Mandar Maju, 1977,

Sunaryo,2002, Perlindungan Hukum Atas Hak Asasi Manusia Bagi Anak Dalam Proses Peradilan Pidana, Fakultas Hukum Unsoed,Purwokerto,

Stanley Oldy Pratasik, Pemidanaan dan Perlindungan Hukum Terhadap Anak yang Menjadi Kurir Narkotika Berdasarkan UndangUndang Nomor 11 Tahun 2012 Tentang Sistem Peradilan Pidana Anak, Jurnal Lex et Societatis
Wagiati Soetodjo, Hukum Pidana Anak, (Bandung: PT.Aditama, 2006. 